\title{
Footprints of the 21st Century Pandemic: Coronavirus History
}

Yeşim Besli

Department of Clinical Microbiology, American Hospital, Istanbul, Turkey

\section{1}

An emerging illness in new-born chickens, characterized by gasping and listless, was described as "An apparently new respiratory disease of chicks" by Schalk and Hwan. Then it was discovered that the disease was communicable; however, the causative agent was yet unknown (1).

\section{6}

Beach and Schalm showed that the cause of a respiratory disease of chicks was a filterable virus (2). The infectious bronchitis virus (IBV) would be the first member of coronaviruses to be reported $(3,4)$.

\section{7}

Beaudette and Hudson succeeded in cultivating and isolating the virus, the cause of infectious bronchitis, for the first time (5).

\section{6}

A new virus, "transmissible infectious gastroenteritis virus (TGEV)", which would be later understood to be linked to coronaviruses, was described as a causative agent of swine enteritis (6).

\section{9}

"Mouse hepatitis coronavirus (MHV)" associated with encephalomyelitis in mice was reported. Though, the connection of MHV with the previously reported two viruses had not been revealed yet (7).

\section{2}

Kendall, Bynoe, and Tyrrell from The British Medical Research Council's Common Cold Research Unit reported that a specimen, marked B814, which had been collected in 1960 from a boy in a residential school suffering from common colds, had not yielded a virus on inoculation into cell culture (8).

\section{Corresponding Author: Yeşim Besli \\ E-mail: ysm5li@hotmail.com}

Received: June 16, 2020 Accepted: August 28, 2020 Published: August 31, 2020

\section{Suggested citation:}

Besli Y. Footprints of the 21st Century Pandemic: Coronavirus History. Infect Dis Clin Microbiol 2020; 2: 121-127.

DOI: $10.36519 / \mathrm{idcm} .2020 .0016$ 


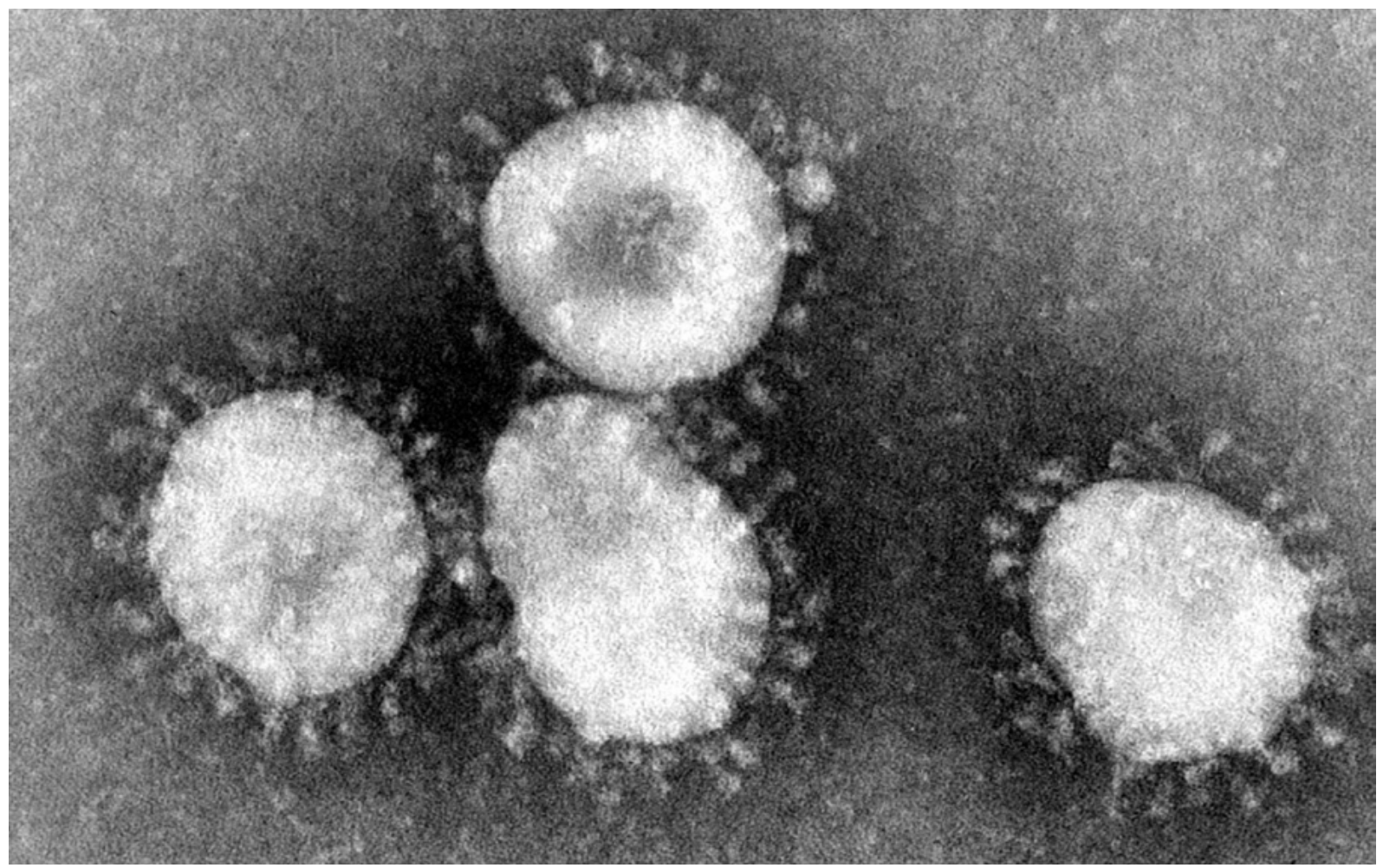

Figure 1. Electron microscopic image of Avian coronavirus. Photo Credit: CDC/Dr. Fred Murphy (1975)

\section{5}

Tyrrell and Bynoe cultivated the virus (B814) in human embryonic tracheal culture and demonstrated that it could still cause colds after inoculation into volunteers (9).

\section{6}

Dorothy Hamre and John J. Procknow from the University of Chicago also reported a new ether sensitive RNA virus isolated during surveillance of upper respiratory infection among medical students in the winter of 1962. After choosing the virus isolated from 229E marked specimen as the prototype strain and cultivating in kidney tissue culture, it was suggested that the new virus was not related to any known human myxoviruses (10).

\section{7}

Mintosh et al. reported six morphologically IBV-like viruses distinct from the myxoviruses. Two of the IBV-like viruses were OC38 and OC43 (OC was used for organ culture), which would be unrevealed to be essentially identical antigenically (11). Almeida and Tyrrell put forward that particles of two novel viruses (B814 and 229E) were indistinguishable and resembled those of infectious bronchitis of chickens based on electron microscopy (Figure 1,2) (12).

\section{8}

Eight virologists (including Almeida, Berry, Cunningham, Hamre, Hofstad, Mallucci, McIntosh, and Tyrrell) agreed on avian infectious bronchitis virus, Mouse hepatitis coronavirus and novel human viruses (B814, 229E, and others) were members of a previously unrecognized group. This new group of viruses was suggested to be called the coronaviruses for their electron microscopy appearance recalling the solar corona (13).

\section{$1889-1890$}

A flu pandemic causing about 1 million deaths, was broke out between 1889-1890. The pandemic, called "Asiatic flu" or "Russian flu", was assumed to be caused by H2N2 influenza after the serological examination. Nevertheless, Vigen et al. claimed the Human Coronavirus OC43 to be the actual causative agent based on their molecular analysis (14). 


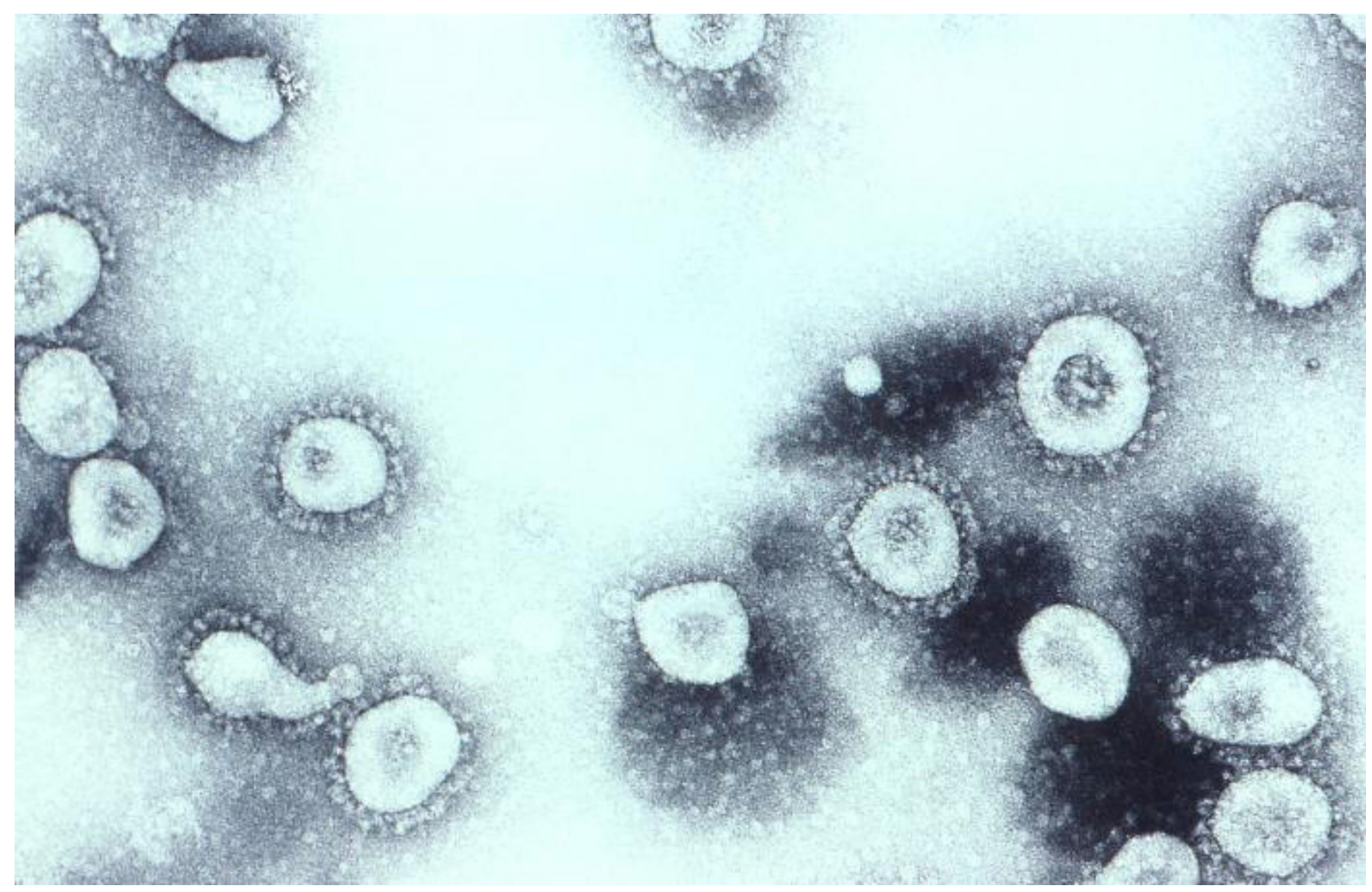

Figure 2. Electron microscopic image of human coronavirus OC43 (Betacoronavirus 1). Photo Credit: CDC/ Dr. Erskine Palmer (1981)

\section{2, NOVEMBER 16}

In Foshan City (Guangdong Province, China), a patient was presented with atypical pneumonia, which was not identified $(15,16)$.

\section{3, FEBRUARY 10}

An email, informing about a mysterious contagious disease with more than 100 dead in a week, was received by the World Health Organization (WHO) Beijing Office (15).

\section{3, FEBRUARY 17}

In Hong Kong, a 33-year-old man died of an unknown reason. He had a travel history with his family to Fujian Province (China) in January. Before this incident, his daughter inexplicably died in China, and his son was hospitalized (15).

\section{3, FEBRUARY 21}

A professor from Zhongshan University in Guangzhou, who treated patients with atypical pneumonia in a Guangzhou hospital in China, stayed at Metropole Hotel in Hong Kong to attend a wedding.
In those days, neither a possibility of any communicable disease was considered nor did the professor suspected himself despite having symptoms for six days. A day later, he would need urgent medical care $(15,17)$.

\section{3, FEBRUARY 23}

A 78-year-old female tourist, who stayed at Metropole Hotel in Hong Kong, returned to Toronto (Canada). Two days later, she developed fever, anorexia, myalgia, a sore throat, and mild non-productive cough $(15,18)$.

\section{3, FEBRUARY 26}

A 48-year-old man with a recent travel history to Shanghai, Guangdong Province, and Macao presented to the French Hospital in Hanoi (Vietnam), he had fever along with respiratory symptoms for three days. He conspicuously had a travel history of being guest in the Metropole Hotel. Dr. Carlo Urbani, a public health specialist of WHO, examined him. Only two days later, his condition would worsen, and several medical staff would show similar symptoms. 
Then Dr. Urbani informed the WHO office in Manila about emerging atypical pneumonia cases $(15,17,19)$.

\section{3, MARCH 1}

A 26-year-old woman with respiratory symptoms applied to the hospital in Singapore. She also had the misfortune of staying at the Hotel Metropole in Hong Kong between 21-25 February $(15,20)$.

\section{3, MARCH 8}

A 54-year-old man had a travel history to Guangdong Province, admitted to hospital due to his respiratory symptoms in Taiwan $(15,21)$.

\section{3, MARCH 15}

WHO named the emerging disease as "Severe acute respiratory syndrome (SARS)" and also announced "a worldwide health threat." Travel recommendations and first case definitions of suspected and confirmed cases were also released by WHO (15).

\section{3, APRIL 16}

WHO released a press briefing and announced the virus causing SARS was officially confirmed to be a novel coronavirus (22). Having animal exposure prior to the developing infection in index cases, aroused the suspicion of animal origin of SARS-CoV. Later, investigations on the virus's genetic determinants would have revealed that the virus emerged through the recombination of bat SARS-related coronaviruses (SARSr-CoVs), the virus-infected civets and humans, and adapted to these hosts before causing the SARS epidemic (23).

\section{3, JULY 5}

Finally, Taiwan was removed the WHO's local transmission list, after Hong Kong, Beijing, and Toronto. A total of 8439 affected people and 812 death from SARS was reported by that time. Besides, approximately $20 \%$ of all cases were health care workers. In other respects, SARS was emphasized as a remaining global threat (24).

\section{4}

A new human coronavirus, "HCoV-NL63", isolated from a 7-month old child with bronchiolitis and conjunctivitis in Amsterdam, Netherland (25). After being reported the first HCoV-NL63 infected case, HCoV-NL63 related infections were observed world-

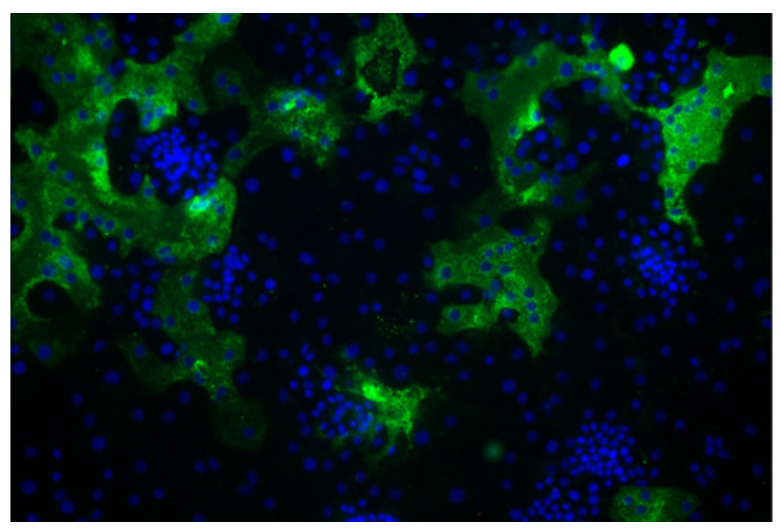

Figure 3. Formation of large syncytia of primary human alveolar type Il cells infected with HCOV-HKU1 (29)

wide (26). Natural hosts of HCoV-NL63 was found to be African bats and the camelids, while an intermediate host was not known (23).

\section{5}

In Hong Kong, another novel coronavirus, "HCoVHKU1", was detected from the respiratory specimens of two adults with pneumonia (27). HCoV-HKU1 was assumed to have rodent related origin (Figure 3)(23).

\section{2, JUNE 13}

In Jeddah (Saudi Arabia), a 60-year-old man with a history of fever, cough, expectoration, and shortness of breath was admitted to a hospital. Genetic analysis of isolated virus from patients' samples unrevealed that the new virus belonged to lineage $\mathrm{C}$ of the genus betacoronavirus, along with the bat coronaviruses HKU4 and HKU5. The novel virus was called "HCoV-EMC (for Erasmus Medical Center)", which would be named as "Mers-CoV" (28). Later, phylogenetic analysis indicated that bats were possible natural host and dromedary camels were likely to be intermediate hosts of Mers-CoV (23).

\section{9, NOVEMBER}

The overall number of laboratories confirmed MersCoV infected cases reached 2494 with 858 cases of death, whereas most of the cases were reported from Saudi Arabia (30).

\section{9, DECEMBER 31}

In Wuhan City (China), mysterious severe pneumonia cases were decelerated by WHO China Country Office (31). 


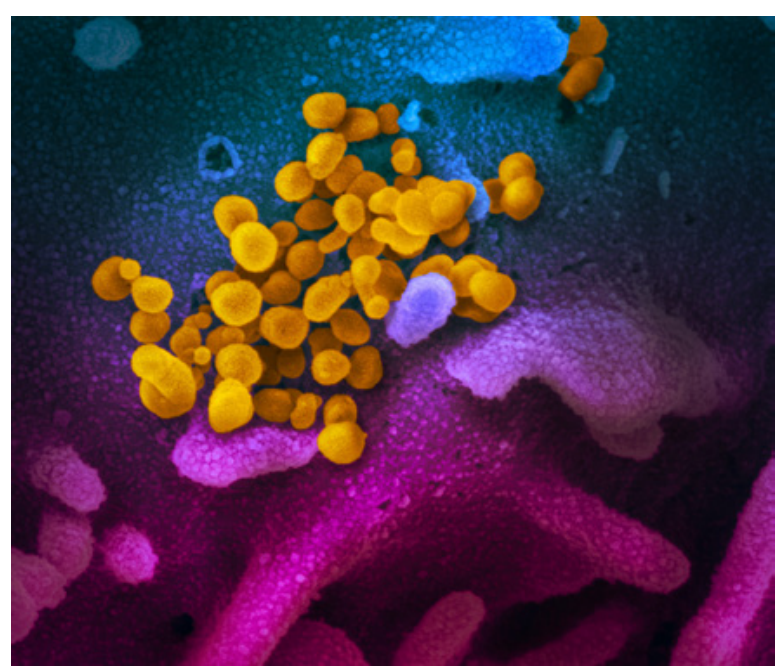

Figure 4. "SARS-CoV-2 (yellow) at cell surface (blue/pink), scanning electron microscope image". Credit: NIAID-RML

\section{0, JANUARY 1}

Pneumonia with unknown etiology was considered linked to the seafood market, since 27 cases had contact with the seafood market in common, and samples from the market tested positive for novel coronavirus. Then, Wuhan's Huanan Seafood Wholesale Market was closed (32).

\section{0, JANUARY 12}

It was officially confirmed that pneumonia cases' causative agent was a virus isolated in broncho alveolar-lavage fluid samples. The novel virus was characterized as a previously unknown betacoronavirus, named 2019-nCoV, which formed a clade within the subgenus sarbecovirus, Orthocoronavirinae subfamily (33). The genetic sequence of COVID-19 was shared by China publicly (34).

\section{0, JANUARY 13}

Thailand officially confirmed the first COVID19 case, which was the first reported case outside China (35).

\section{0, JANUARY 16}

In Japan, the first COVID-19 case was reported in a patient with a travel history to Wuhan (36).

\section{0, JANUARY 19}

A 35-year-old man with a 4-day history of cough and fever returned from Wuhan on January 15, ad- mitted to an urgent care clinic in Washington. He was the first COVID-19 case in the USA (37).

\section{0, JANUARY 23}

Chinese authorities banned all of Wuhan's intercity travels and restricted movements in the Wuhan city, so the city was now aquatinted (38).

\section{0, JANUARY 24}

France reported the first COVID19 case, who had a travel history to China, and it was the first COVID-19 case to be reported across Europe (32).

\section{0, JANUARY 30}

WHO declared a "public health emergency of international concern" for COVID-19 outbreak (38).

\section{0, FEBRUARY 1}

The first COVID-19 death outside of China mainland was reported in the Philippines (39).

\section{0, FEBRUARY 3}

The Diamond Princess Cruise ship with boarding a total of 2666 passengers (1281 of whom were Japanese and 1045 crew members from 56 countries) was anchored at the Yokohama Port and then aquatinted for 14 days, because an 80-year-old male passenger on the cruise ship was diagnosed as COVID-19 pneumonia on February 1 (40).

\section{0, FEBRUARY 13}

New coronavirus, cause of the outbreak, named "severe acute respiratory syndrome coronavirus 2 (SARS-CoV-2)", while the disease was officially called "coronavirus disease (COVID-19)" by WHO (41).

\section{0, FEBRUARY 19}

Iran officially announced the first COVID-19 deaths (42).

\section{0, FEBRUARY 22}

COVID-19 cluster of cases from Lombardy and the other two regions (Piedmont and Veneto) of Italy was reported (43).

\section{0, MARCH 11}

COVID-19 was stated as a pandemic by WHO (44). 
Peer-review: Externally peer-reviewed

Conflict of Interest: The author have no conflict of interest to declare.
Financial Disclosure: The author declared that this study has received no financial support.

\section{REFERENCES}

1 Fabricant J. The early history of infectious bronchitis. Avian diseases 1998; 42:648-650.

2 Schalk AE, Hawn MC. An appar- ently new respiratory disease of chicks. J. Am. Vet. Med. Assoc. 78:413-422. 1931.

3 Decaro N. Gammacoronavirus. Tidona C, Darai G, editors. Gammacoronavirus: Coronaviridae. The Springer Index of Viruses. New York: Springer; 2011. pp. 403-413.

4 Beach JR, Schalm OW. A filterable virus, distinct from that of laryngotracheitis, the cause of a respiratory disease of chicks. Poultry Science 1936; 15:199-206

5 Beaudette, E R., and C. B. Hudson. Cultivation of the virus of infectious bronchitis. J. Am. Vet. Med. Assoc. 90:51-58. 1937.

6 Doyle LP, Hutchings LM. A transmissible gastroenteritis in pigs. J Am Vet Med Assoc. 1946; 108:257-259.

7 Cheever, F.S., Daniels, J.B., Pappenheimer, A.M., Bailey, O.T. (1949). A murine virus (JHM) causing disseminated encephalomyelitis with extensive destruction of myelin: I. Isolation and biological properties of the virus. The Journal of Experimental Medicine, 90(3), 181-194

8 Kendall EJC. Bynoe ML, Tyrrell DAJ. Virus isolations from common colds occurring in a residential school. Br Med J 1962; 2: 82-86

9 Tyrrell DAJ, Bynoe ML. Cultivation of a novel type of common-cold virus in organ cultures. Br Med J 1965; 1: 1467-1470.

10 Hamre D, Procknow Jj. A new virus isolated from the human respiratory tract. Proc Soc Exp Biol Med 1966; 121:190-3.

11 McIntosh K, Dees JH, Becker WB, Kapikian AZ, Chanock RM. Recovery in tracheal organ cultures of novel viruses from patients with respiratory disease. Proc Natl Acad Sci USA. 1967; 57: 933-940

12 Almeida JD, Tyrrell DAJ. The morphology of three previously uncharacterized human respiratory viruses that grow in organ culture free. J Gen Virol 1967; 1:175-8.

13 Almeida JD, Berry DM, Cunningham CH, Hamre D, Hofstad MS, Mallucci L, et al. Virology: Coronaviruses. Nature 1968; 220: 650 .

14 Vijgen L, Keyaerts E, Moës E, Thoelen I, Wollants E, Lemey P et al. Complete genomic sequence of human coronavirus OC43: molecular clock analysis suggests a relatively recent zoonotic coronavirus transmission event. J Virol. 2005; 79:1595-604.

15 World Health Organization (WHO). Update 95 - SARS: Chronology of a serial killer. Available at: https://www.who. int/csr/don/2003 07 04/en/

$16 \mathrm{Xu}$ RH, He JF, Evans MR, Peng GW, Field HE, Yu DW, et al. Epidemiologic Clues to SARS Origin in China. Emerg Infect Dis 2004; 10: 1030-1037.

17 Hung SL. The SARS epidemic in Hong Kong: what lessons have we learned? J R Soc Med 2003; 96: 374-378.

18 Poutanen SM, Low DE, Henry B, Finkelstein S, Rose D, Green K, et al. Identification of severe acute respiratory syndrome in Canada. N Engl J Med 2003; 348:1995-2005

19 Fleck F. Carlo Urbani. BMJ 2003; 326): 825.

20 Hsu LY, Lee CC, Green JA, Ang B, Paton NI, Lee L et al . Severe Acute Respiratory Syndrome (SARS) in Singapore: Clinical Features of Index Patient and Initial Contacts. Emerg Infect Dis. 2003; 9: 713-717

21 Chen KT, Twu SJ, Chang HL, Wu YC, Chen CT, Lin TH et al. SARS in Taiwan: an overview and lessons learned. Int J Infect Dis. 2005; 9: 77-85.

22 World Health Organization (WHO). Severe Acute Respiratory Syndrome - Press briefing Wednesday, 16 April, 13:30 Palais des Nations. Available at: https://www.who.int/csr/ sars/2003_04_16/en/

23 Cui J, Li F, Shi ZL. Origin and evolution of pathogenic coronaviruses. Nat Rev Microbiol. 2019; 17:181-192.

24 World Health Organization (WHO). SARS outbreak contained worldwide, Geneva, 5 July 2003. Available at: https://www. who.int/mediacentre/news/releases/2003/pr56/en/

25 van der Hoek L, Pyrc K, Jebbink MF, Vermeulen-Oost W, Berkhout RJM, Wolthers KC, et al. Identification of a new human coronavirus. Nat Med 2004; 10;368-373.

26 van der Hoek L, Pyrc K, Berkhout B. Human coronavirus NL63, a new respiratory virus. FEMS Microbiol Rev 2006;30: 760-773.

27 Vabret A, Dina J, Gouarin S, Petitjean J, Corbet S, Freymuth F. Detection of the New Human Coronavirus HKU1: A Report of 6 Cases. Clin Infect Dis 2006; 42:634-639.

28 Zaki AM, van Boheemen S, Bestebroer TM, Osterhaus ADME, Fouchier RAM. Isolation of a Novel Coronavirus from a Man with Pneumonia in Saudi Arabia. N Engl J Med 2012; 367:1814-1820

29 Dominguez, S. R., Travanty, E. A., Qian, Z., \& Mason, R. J. (2013). Human coronavirus HKU1 infection of primary human type II alveolar epithelial cells: cytopathic effects and innate immune response. PLoS One. 2013; 8: e70129. 
30 World Health Organization (WHO). Middle East respiratory syndrome coronavirus (MERS-CoV) monthly summary, November 2019. Available at:https://www.who.int/emergencies/ mers-cov/en/

31 World Health Organization (WHO). Pneumonia of unknown cause - China, Disease outbreak news, 5 January 2020. Available at: https://www.who.int/csr/don/05-january-2020-pneumonia-of-unkown-cause-china/en/

32 European Centre for Disease Prevention and Control (ECDC). Event background COVID-19. Available at: https://www.ecdc. europa.eu/en/novel-coronavirus/event-background-2019

33 Zhu N, Zhang D, Wang W, Li X, Yang B, Song J. A Novel Coronavirus from Patients with Pneumonia in China, 2019. N Engl J Med 2020; 382:727-733

34 World Health Organization (WHO). WHO Timeline - COVID-19, Last updated 27 April. Available at: https://www.who.int/ news-room/detail/27-04-2020-who-timeline---covid-19

35 World Health Organization (WHO). Novel Coronavirus Thailand (ex-China) Disease outbreak news, 14 January 2020. Available at: https://www.who.int/csr/don/14-january-2020-novel-coronavirus-thailand-ex-china/en/

36 World Health Organization (WHO). Novel Coronavirus - Japan (ex-China) Disease outbreak news, 16 January 2020. Available at: https://www.who.int/csr/don/16-january-2020-novel-coronavirus-japan-ex-china/en/

37 Holshue ML, DeBolt C, Lindquist S, Lofy KH, Wiesman J, Bruce H. First Case of 2019 Novel Coronavirus in the United States. N Engl J Med 2020; 382:929-936.

38 World Health Organization (WHO). Statement on the second meeting of the International Health Regulations (2005) Emergency Committee regarding the outbreak of novel coronavirus (2019-nCoV), 23 January 2020. Available at: https://www. who.int/news-room/detail/23-01-2020-statement-on-themeeting-of-the-international-health-regulations-(2005)-emergency-committee-regarding-the-outbreak-of-novel-coronavirus-(2019-ncov)
39 Edrada EM, Lopez EB, Villarama JB, Salva Villarama EP, Dagoc BF, Smith C. First COVID-19 Infections in the Philippines: A Case Report Trop Med Health 2020; 14:21.

40 Nakazawa E, Ino H, Akabayashi A. Chronology of COVID-19 Cases on the Diamond Princess Cruise Ship and Ethical Considerations: A Report from Japan. Disaster Med Public Health Prep 2020:1-8.

41 World Health Organization (WHO). Naming the coronavirus disease (COVID-19) and the virus that causes it. Available at: https://www.who.int/emergencies/diseases/novel-coronavirus-2019/technical-guidance/naming-the-coronavirus-disease-(covid-2019)-and-the-virus-that-causes-it

42 Takian A, Raoofi A, Kazempour-Ardebilid S. COVID-19 battle during the toughest sanctions against Iran. Lancet. 2020; 395:1035-1036.

43 European Centre for Disease Prevention and Control (ECDC). Threat assessment brief: Outbreak of novel coronavirus disease 2019 (COVID-19): Situation in Italy, 23 Feb 2020. Available at: https://www.ecdc.europa.eu/en/publications-data/ outbreak-novel-coronavirus-disease-2019-covid-19-situation-italy

44 World Health Organization (WHO). WHO Director-General's opening remarks at the media briefing on COVID-19, 11 March 2020. Available at: https://www.who.int/dg/speeches/ detail/who-director-general-s-opening-remarks-at-the-media-briefing-on-covid-19---11-march-2020 